\title{
FEBUKO and MODMEP: Field measurements and modelling of aerosol and cloud multiphase processes
}

H. Herrmann ${ }^{\mathrm{a}, *}$, R. Wolke ${ }^{\mathrm{a}}$, K. Müller ${ }^{\mathrm{a}}$, E. Brüggemann ${ }^{\mathrm{a}}$, T. Gnauk ${ }^{\mathrm{a}}$, P. Barzaghi ${ }^{\mathrm{a}}$, S. Mertes ${ }^{\mathrm{a}}$, K. Lehmann ${ }^{\mathrm{a}}$, A. Massling ${ }^{\mathrm{a}}$, W. Birmili ${ }^{\mathrm{a}}$, A. Wiedensohler ${ }^{\mathrm{a}}$, W. Wieprecht ${ }^{\mathrm{b}}$, K. Acker ${ }^{\mathrm{b}}$, W. Jaeschke ${ }^{\mathrm{c}}$, H. Kramberger ${ }^{\mathrm{d}}$, B. Svrcina ${ }^{\text {d }}$, K. Bächmann ${ }^{\text {d }}$, J.L. Collett Jr. ${ }^{\text {e }}$, D. Galgon ${ }^{a}$, K. Schwirn ${ }^{\mathrm{a}}$, A. Nowak ${ }^{\mathrm{a}}$, D. van Pinxteren ${ }^{\mathrm{a}}$, A. Plewka ${ }^{\mathrm{a}}$, R. Chemnitzer ${ }^{\mathrm{a}}$, C. Rüd ${ }^{\mathrm{a}}$, D. Hofmann ${ }^{\mathrm{a}}$, A. Tilgner ${ }^{\mathrm{a}}$, K. Diehl ${ }^{\mathrm{a}}$, B. Heinold ${ }^{\mathrm{a}}$, D. Hinneburg ${ }^{\mathrm{a}}$, O. Knoth ${ }^{\mathrm{a}}$, A.M. Sehili ${ }^{\mathrm{a}}$, M. Simmel ${ }^{\mathrm{a}}$, S. Wurzler ${ }^{\mathrm{a}}$, Z. Majdik ${ }^{\mathrm{a}}$, G. Mauersberger ${ }^{\mathrm{b}}$, F. Müller ${ }^{\mathrm{f}}$

${ }^{a}$ Leibniz-Institut für Troposphärenforschung, Permoserstr. 15, 04318 Leipzig, Germany

${ }^{\mathrm{b}}$ Brandenburgische Technische Universität Cottbus, Lehrstuhl für Luftchemie und Luftreinhaltung, Volmer Str.13, 12489 Berlin, Germany 'Johann-Wolfgang-Goethe Universität Frankfurt, Zentrum für Umweltforschung, Georg-Voigt-Str. 14, 60325 Frankfurt a.M., Germany

${ }^{\mathrm{d}}$ Institut für Anorganische Chemie, Technische Universität Darmstadt, Petersenstrasse 18, 64287 Darmstadt, Germany

e Atmospheric Science Department, Colorado State University, Fort Collins, USA

${ }^{\mathrm{f}}$ Max-Planck Institut für Meteorologie, Bundesstrasse 53, 20146 Hamburg, Germany

\begin{abstract}
An overview of the two FEBUKO aerosol-cloud interaction field experiments in the Thüringer Wald (Germany) in October 2001 and 2002 and the corresponding modelling project MODMEP is given. Experimentally, a variety of measurement methods were deployed to probe the gas phase, particles and cloud droplets at three sites upwind, downwind and within an orographic cloud with special emphasis on the budgets and interconversions of organic gas and particle phase constituents. Out of a total of 14 sampling periods within 30 cloud events three events (EI, EII and EIII) are selected for detailed analysis. At various occasions an impact of the cloud process on particle chemical composition such as on the organic compounds content, sulphate and nitrate and also on particle size distributions and particle mass is observed. Moreover, direct phase transfer of polar organic compound from the gas phase is found to be very important for the understanding of cloudwater composition.

For the modelling side, a main result of the MODMEP project is the development of a cloud model, which combines a complex multiphase chemistry with detailed microphysics. Both components are described in a fine-resolved particle/ drop spectrum. New numerical methods are developed for an efficient solution of the entire complex model. A further development of the CAPRAM mechanism has lead to a more detailed description of tropospheric aqueous phase organic chemistry. In parallel, effective tools for the reduction of highly complex reaction schemes are provided.
\end{abstract}

\footnotetext{
*Corresponding author. Tel.: + 493412352446 ; fax: +49341 2352325.

E-mail address: herrmann@tropos.de (H. Herrmann).
} 
Techniques are provided and tested which allow the description of complex multiphase chemistry and of detailed microphysics in multidimensional chemistry-transport models.

(C) 2005 Elsevier Ltd. All rights reserved.

Keywords: Hill cap cloud experiment; Aerosol; Cloud water; Trace gases; Physico-chemical analysis

\section{Introduction}

The interaction of particular matter and trace gases in orographic clouds has been studied before under different aspects in Europe: at Kleiner Feldberg (continental frontal clouds, autumn 1990, Wobrock et al., 1994), at Great Dun Fell (marine orographic clouds, spring 1993 and 1995, Choularton et al., 1997; Bower et al., 1999), at the Puy de Dôme (cloud ice mountain experiment 1998, Wobrock et al., 2001) and at Tenerife (marine orographic clouds, ACE-2, summer 1997, Raes et al., 2000). The interaction between aerosols and clouds has also been studied in the USA, see for example Collett et al. (2002) and Feingold and Kreidenweis (2000). Here, field experiments of aerosol-cloud interactions that were conducted at the Schmücke, a mountain located in central Germany, are described.
These studies were coordinated under the code name FEBUKO (Field Investigations of Budgets and Conversions of Particle Phase Organics in Tropospheric Cloud Processes). The experiments were carried out in October 2001 and 2002. From a greater number of observations three cloud events were selected for a detailed analysis and discussed below. Times and duration of the measurement periods for the three events are given in Table 1 together with the principal meteorological parameters observed.

Modelling studies have previously indicated that the interaction of trace gases with the liquid phase of clouds modifies also the chemistry in the gas phase (e.g. Lelieveld and Crutzen, 1991; Kreidenweis et al., 2003). In general, the complexities resulting from the interplay of physical and chemical cloud processes have discouraged investigators from simultaneously treating all

Table 1

Meteorological key parameters for the three main events

\begin{tabular}{|c|c|c|c|c|c|c|c|c|}
\hline \multirow[t]{2}{*}{ Date, Event } & \multirow[t]{2}{*}{ Time UTC } & \multirow{2}{*}{$\begin{array}{l}\text { Wind speed } \\
\left(\mathrm{m} \mathrm{s}^{-1}\right) \text { and } \\
\text { direction } \\
(\mathrm{deg})\end{array}$} & \multirow{2}{*}{$\begin{array}{l}\text { Air } \\
\text { pressure } \\
(\mathrm{hPa})\end{array}$} & \multirow[t]{2}{*}{ Temp. $\left({ }^{\circ} \mathrm{C}\right)$} & \multirow{2}{*}{$\begin{array}{l}\text { LWC } \\
\left(\mathrm{g} \mathrm{m}^{-3}\right)\end{array}$} & \multirow{2}{*}{$\begin{array}{l}\text { Cloud base } \\
\text { height (m) } \\
\text { above } \\
\text { upwind site }\end{array}$} & \multicolumn{2}{|c|}{ Relative humidity $(\%)$} \\
\hline & & & & & & & $\begin{array}{l}\text { Upwind } \\
\text { site }\end{array}$ & $\begin{array}{l}\text { Downwind } \\
\text { site }\end{array}$ \\
\hline \multirow[t]{3}{*}{$\begin{array}{l}06-08 \\
\text { October } 2001 \\
\text { event EII }\end{array}$} & $10: 30-14: 15$ & $\begin{array}{l}5.0-7.8 \\
(6.2)^{*} \\
210-230 ; \\
(221.7)\end{array}$ & $\begin{array}{l}905.1-905.5 \\
(905.3)\end{array}$ & $\begin{array}{l}9.3-11.5 \\
(10.6)\end{array}$ & $\begin{array}{l}0.000-0.251 \\
(0.049)\end{array}$ & $\begin{array}{l}270-340 \\
(318.5)\end{array}$ & $\begin{array}{l}79-94 \\
(85.5)\end{array}$ & $\begin{array}{l}81.2-85.9 \\
(83.6)\end{array}$ \\
\hline & $13: 15-15: 15$ & $\begin{array}{l}2.2-5.2 ; \\
(4.0) \\
200-250 ; \\
(225.8)\end{array}$ & $\begin{array}{l}902.7-903.3 \\
(903.1)\end{array}$ & $\begin{array}{l}10.5-11.0 \\
(10.7)\end{array}$ & $\begin{array}{l}0.000-0.456 \\
(0.153)\end{array}$ & $\begin{array}{l}90-210 \\
(122.2)\end{array}$ & $\begin{array}{l}100 \\
\text { Constant }\end{array}$ & $\begin{array}{l}86.9-89.6 \\
(88.4)\end{array}$ \\
\hline & 18:00-11:15 & $\begin{array}{l}2.7-9.8 ; \\
(6.9) \\
180-220 ; \\
(207.1)\end{array}$ & $\begin{array}{l}900.9-903.0 \\
(901.9)\end{array}$ & $\begin{array}{l}9.4-9.9 \\
(9.6)\end{array}$ & $\begin{array}{l}0.000-0.512 \\
(0.203)\end{array}$ & $\begin{array}{l}50-320 \\
(191.0)\end{array}$ & $\begin{array}{l}86-100 \\
(98.5)\end{array}$ & $\begin{array}{l}78.5-93.6 \\
(89.2)\end{array}$ \\
\hline $\begin{array}{l}26 / 27 \\
\text { October } 2001 \\
\text { event EI }\end{array}$ & $22: 00-13: 00$ & $\begin{array}{l}5.1-10.9 ; \\
(8.0) \\
210-230 ; \\
(216.3)\end{array}$ & $\begin{array}{l}909.0-910.6 \\
(909.8)\end{array}$ & $\begin{array}{l}5.4-7.5 \\
(6.1)\end{array}$ & $\begin{array}{l}0.109-0.665 \\
(0.335)\end{array}$ & $\begin{array}{l}50-210 \\
(115.6)\end{array}$ & $\begin{array}{l}95-100 \\
(99.3)\end{array}$ & $\mathrm{n} / \mathrm{a}$ \\
\hline $\begin{array}{l}16 / 17 \\
\text { October } 2002 \\
\text { event EIII }\end{array}$ & $21: 00-05: 30$ & $\begin{array}{l}7.6-12.3 ; \\
(10.1) \\
210-220 ; \\
(215.2)\end{array}$ & $\begin{array}{l}891.1-893.3 \\
(892.4)\end{array}$ & $\begin{array}{l}7.1-9.3 \\
(7.9)\end{array}$ & $\begin{array}{l}0.024-0.417 \\
(0.202)\end{array}$ & $\begin{array}{l}140-290 \\
(218.8)\end{array}$ & $\mathrm{n} / \mathrm{a}$ & $\begin{array}{l}90.3-97.2 \\
(93.2)\end{array}$ \\
\hline
\end{tabular}

n/a: not available

*number in parenthesis represent the mean value. 
aspects of multiphase chemistry with equal rigor. Thus, many models focus either on the complex multiphase chemistry in only a few aggregated drops size classes (Audiffren et al., 1998; Herrmann et al., 2000; Djouad et al., 2003), or on the details of microphysics by assuming strongly simplified chemical mechanisms (Bott, 1999; Fahey and Pandis, 2001). The recent development of more sophisticated cloud models that incorporate more comprehensive chemical mechanisms now makes it possible to study the interaction between microphysical and multiphase chemical processes in greater detail (e.g. Leriche et al., 2000, 2003). The rate of chemical conversions in cloud drops is essentially determined by the rate of mass transfer between the gas and the liquid phases. Numerical studies show that much attention must be paid to the dynamics of the inter-phase transfer (Audiffren et al., 1998; Djouad et al., 2003), and that the mass transfer depends strongly on the surface area of the inter-phase boundaries (Fahey and Pandis, 2001; Kreidenweis et al., 2003). Therefore, any description of multiphase processes should consider a sufficiently well-resolved drop size spectrum.

\section{Motivation}

The aim of the coupled project clusters FEBUKO and MODMEP ("MODelling of MultiphasE Processes: Tools and chemical mechanisms") has been to perform aerosol-cloud interaction hill cap cloud field experiments with special emphasis on the chemical and physical characterisation of particles throughout their transition from $\mathrm{CCN}$ (cloud condensation nuclei) to cloud droplets and back to processed particles. Special emphasis was laid on a most detailed characterisation of organic compounds in particles encountered at each stage of the mentioned process chain. Within MODMEP complex models and modelling tools have been developed and the coupled microphysics/ chemistry model SPACCIM (Spectral Aerosol Cloud Interaction Model) has been applied for the interpretation of the FEBUKO experiments and a comparison of measured data and modelled data for a complex multiphase chemistry model to assess the current state of performance of multiphase models. In this manner, the comparison of measurements and model simulations led to a better comprehension of the processes involved, while it also provided indications in which way the models might be further improved. In this context, the mechanism CAPRAM 3.0 (Chemical Aqueous Phase Radical Mechanism) has been developed which aims at the better description of aqueous phase tropospheric chemistry including reactions of essentially up to four carbon atoms.

\section{Experimental}

\subsection{Site description}

The Thüringer Wald is a low mountain range in central Germany, which extends in south-easterly direction without any important crossing valleys. The research station Schmücke of the German Weather Service (Deutscher Wetterdienst, DWD) and the Federal Environmental Office (Umweltbundesamt, UBA) is located near the summit of the mountain $\left(10^{\circ} 46^{\prime} 15^{\prime \prime}\right.$ East, $50^{\circ} 39^{\prime} 19^{\prime \prime}$ North, $937 \mathrm{~m}$ above sea level), which is in the vicinity of the highest peak of the Thüringer Wald (982 $\mathrm{m}$ a.s.l.). A model of the terrain is shown in Fig. 1. The air masses encountered at the DWD/UBA station Schmücke (summit site $\mathrm{S}$ ) are typically composed of aged air, which is first influenced by anthropogenic emissions from Western Europe (Italy, Switzerland, France, Belgium and Germany), and is subsequently exposed to biogenic emissions on its way from the Rhine-Main area to the Thüringer Wald. No anthropogenic aerosol sources exist within $120 \mathrm{~km}$ distance toward the south-west. This sector was selected as the area of preferred wind direction for the experiments. In October, the UBA station becomes immersed in clouds on 25 days, on average. In many cases, this is an orographic cloud so that the station is well suited for cloud experiments. The air flow over the station is assessed both by modelling and by tracer experiments. For this purpose, two additional experimental sites were established at Goldlauter (upwind site, U; $10^{\circ} 45^{\prime} 20^{\prime \prime}$ East, $50^{\circ} 38^{\prime} 25^{\prime \prime}$ North, $605 \mathrm{~m}$ a.s.1.) and at Gehlberg (downwind site D; $10^{\circ} 47^{\prime} 32^{\prime \prime}$ East, 50 40'21" North, $732 \mathrm{~m}$ a.s.1.). Under conditions of south-westerly winds the air masses are guided from Goldlauter via the summit toward Gehlberg as shown in Fig. 2, which presents a cross section of the mountain range. The orographic terrain and the air flow conditions are

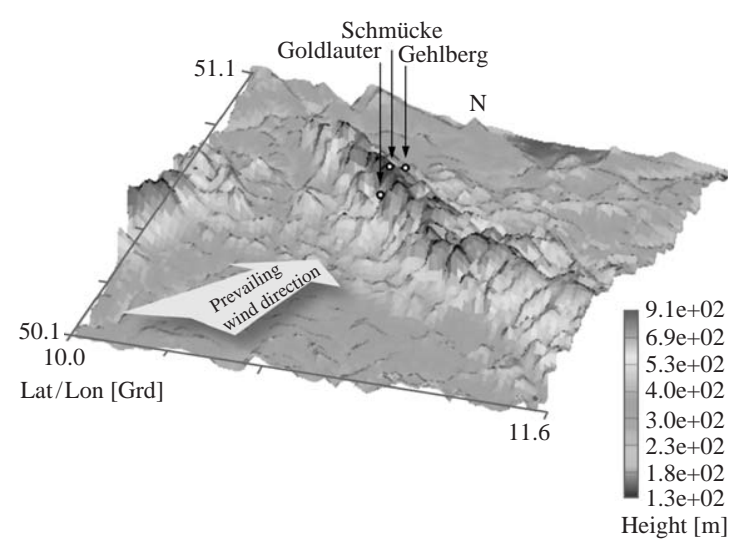

Fig. 1. Map of Central Germany with the marked area of investigations (magnified). 


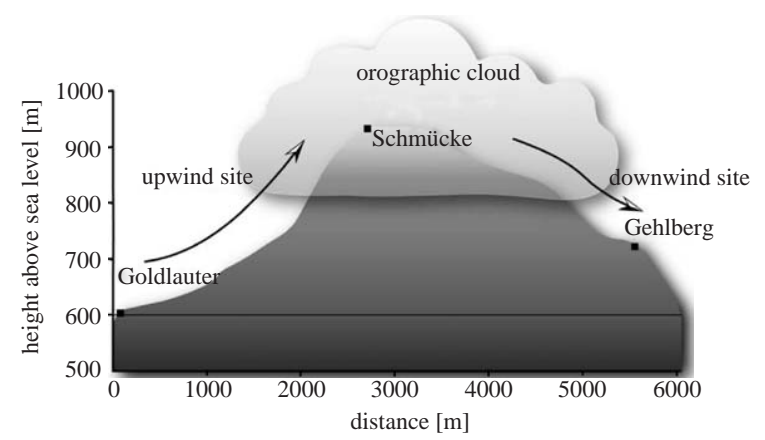

Fig. 2. Cross section of the Thüringer Wald at Goldlauter, Schmücke and Gehlberg.

Table 2

Local climate characterisation of the Thüringer Wald at Schmücke in October based on data for the period 1981-1990

\begin{tabular}{|c|c|c|c|}
\hline & $\begin{array}{l}\text { Climatic } \\
\text { mean }^{\mathrm{a}}\end{array}$ & $\begin{array}{l}\text { October } \\
2001\end{array}$ & $\begin{array}{l}\text { October } \\
2002\end{array}$ \\
\hline $\begin{array}{l}\text { Mean temperature } \\
\left({ }^{\circ} \mathrm{C}\right)\end{array}$ & 5.7 & 9.2 & 3.8 \\
\hline $\begin{array}{l}\text { Max. temperature } \\
\left({ }^{\circ} \mathrm{C}\right)\end{array}$ & 21.8 & 19.3 & 13.6 \\
\hline $\begin{array}{l}\text { Min. temperature } \\
\left({ }^{\circ} \mathrm{C}\right)\end{array}$ & -7.1 & 1.5 & -2.5 \\
\hline Precipitation (mm) & 97 & 80 & 207 \\
\hline Days with Fog & 24.9 & 28 & 29 \\
\hline $\begin{array}{l}\text { Days with prec. } \\
>0.1 \mathrm{~mm}\end{array}$ & 17.4 & 14 & 23 \\
\hline $\begin{array}{l}\text { Days with prec. } \\
>1.0 \mathrm{~mm}\end{array}$ & 13.2 & 11 & 16 \\
\hline $\begin{array}{l}\text { Days with } \\
\text { snowfall }\end{array}$ & - & 1 & 10 \\
\hline $\begin{array}{l}\text { Mean relative } \\
\text { humidity }(\%)\end{array}$ & - & 92 & 97 \\
\hline Sun shine (h) & 102 & 97 & 44 \\
\hline $\begin{array}{l}\text { Wind from SW } \\
(\%)\end{array}$ & 57 & 75 & 32 \\
\hline
\end{tabular}

${ }^{\mathrm{a}}$ Supplied by DWD.

further examined in the contribution of Heinold et al. (2005). Between the three measurement sites lies a small road with only occasional traffic. The dominant trees in the region are Norway spruces $(8-23 \mathrm{~m})$. Wet deposition occurs on their needles in the presence of clouds, dry deposition occurs at all levels below the cloud. Table 1 summarises key meteorological data observed during the measurement periods.

\subsection{Local climate}

Table 2 provides a summary of climatic conditions experienced at the Schmücke station. Fig. 3 further

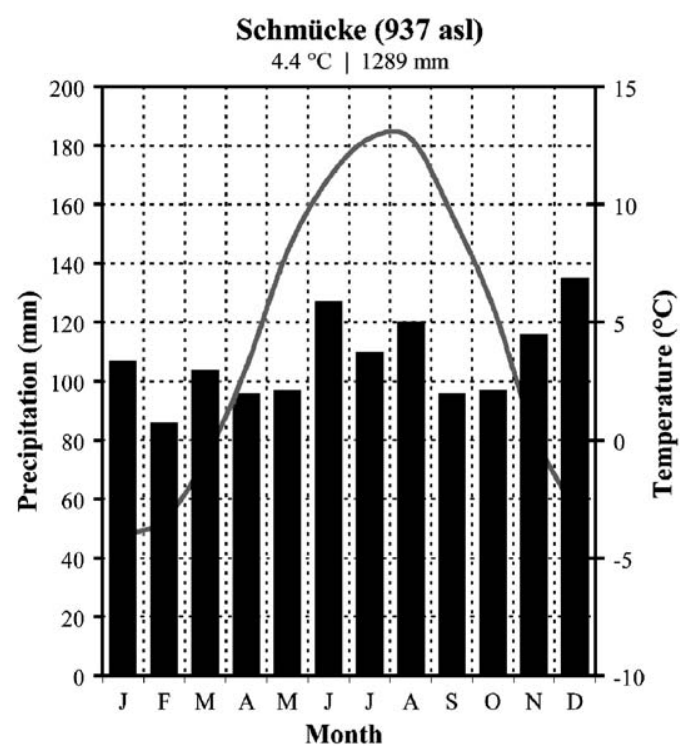

Fig. 3. Local climate diagram for the Schmücke based on data of 1981-1990, modified after http://www.klimadiagramme.de/ Deutschland/schmuecke.html

provides the annual ranges of temperature and precipitation. The local climate is characterised by fairly high levels of orographic precipitation, occurring upwind of the mountain range. The precipitation in the higher regions of the Thüringer Wald can reach up to $1300 \mathrm{~mm}$ annually, and still is about $700 \mathrm{~mm}$ during the winter half year. In the downwind regions, the lower regions of the so-called Thüringer Becken, the level of precipitation falls to $200 \mathrm{~mm}$ annually. These effects are caused by the prevailing south-westerly winds. Fig. 4 shows the average distribution of wind direction at the station Schmücke. Foggy days are observed at the Schmücke on about 170 days per year. For a number of such events, the fog is in fact better described as an orographic cloud due to the uplift of air from the Goldlauter site toward the Schmücke summit. In October, the wind direction is to $57 \%$ from the southwest, in the $210-250^{\circ}$ sector of the wind rose. As outlined in Tilgner et al. (2005a,b) and Table 2, this weather situation occurred in October 2001 on 18 days with south-westerly wind being observed in $75 \%$ of the cases. In October 2002, the frequencies were 9 days and $32 \%$, respectively. In general, the conditions encountered in October 2001 differed little from the long-term mean, whereas in October 2002 the weather was significantly colder and wetter than the long-term mean. This had consequences for the performance of the experiments, because the necessary experimental conditions were much better achieved in October 2001 than in October 2002. 


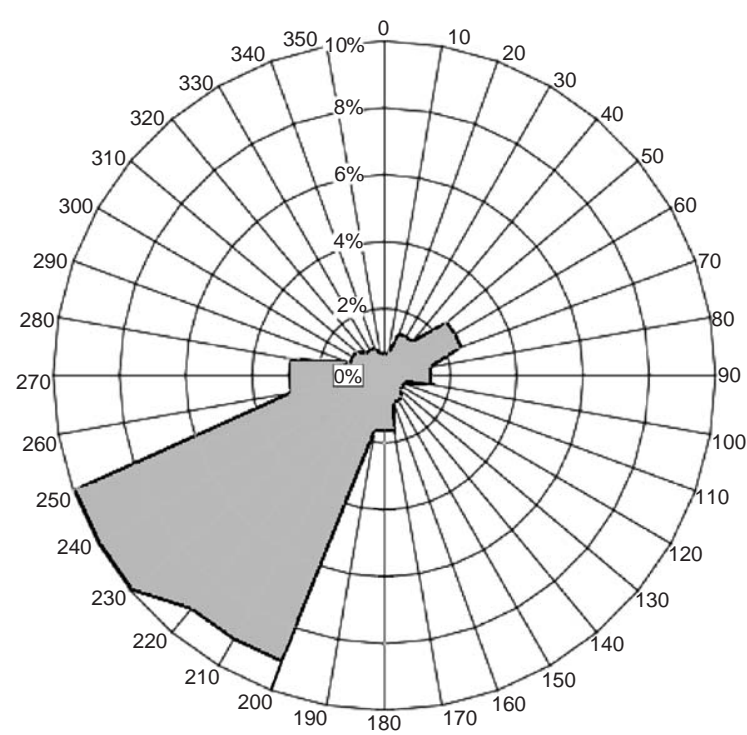

Fig. 4. Wind rose for the Schücke mountain (average of 1981-1990), from weather data of the DWD at the Schmücke research station.

\subsection{Sampling equipment, experimental techniques and quality control}

Table 3 provides a summary of measurement techniques employed and participating group responsibilities. Tables 4 and 5 list further specifications of individual instruments. Mobile equipment for the sampling of trace gases and particle was installed at the upwind (U) and at the downwind (D) sites. At the summit a $20 \mathrm{~m}$ height tower was installed for the placement of cloud water collectors and for the determination of the liquid water content (LWC). A set of different active cloud water collectors was employed for bulk and size-segregated sampling (for details see Wieprecht et al., 2005). Another set of instruments was placed in a window on the top floor of the station building located at the summit, facing the upwind direction, to collect droplets by two counter-flow virtual impactors (CVI) and interstitial aerosol particles by a droplet-segregating inertial impactor (INT), both of which have been described previously by Schwarzenböck et al. (2000). These devices were used in combination with filters to sample residual nuclei from evaporated cloud drops, and with adsorption tubes for the collection of organic carbonyl compounds, respectively. The number size distributions of interstitial particles and of the cloud drop residual particles were determined by means of two differential mobility particle sizing (DMPS) systems. Meteorological data and the main trace measurements at the summit were provided by the staff of the DWD and UBA. Meteorological data at all three sites are necessary to decide whether conditions are suitable for conducting and/or analysing the cloud experiments. The relevant parameters were used for a synopsis of the situation, on the basis of which further action was taken. Altogether 14 cloud events were explored, but only three were found suitable for further investigation (Tilgner et al., 2005a). The key meteorological data for these are summarised in Table 1.

\subsubsection{Gas phase trace components}

Tracer experiments were performed with SF6 to demonstrate the existence of a connected air flow from the upwind site via the summit to the downwind site. Standard trace gases $\left(\mathrm{O}_{3}, \mathrm{SO}_{2}, \mathrm{NO}_{x}\right.$ and $\left.\mathrm{CO}\right)$ were measured at all three sites in order to obtain additional data that can be used to asses the air flow over the mountain ridge. Ozone and carbon monoxide were found to provide useful data for his purpose. Other oxidised compounds provide information on the quality of the encountered air masses. The inorganic compounds $\mathrm{NO}_{x}$, other reactive nitrogen compounds $\mathrm{NO}_{y}$, nitrous and nitric acids, and non-methane hydrocarbons (NMHC) were measured at the upwind site because they provide information on the extent of ageing, contamination or the oxidation capacity of the encountered air masses. Hydrogen peroxide, carbonyl compounds, and organic acids were measured at the upwind site as well as at the downwind site.

\subsubsection{Aerosol and cloud physics parameters}

The physical characterisation of the aerosol particles includes measurement of the number size distribution in the range $D_{\mathrm{p}}=3-900 \mathrm{~nm}$ at all three sites, as well as the hygroscopicity of the particles at the upwind site. Changes in the size distribution between the upwind and the downwind site provide an indication for possible growth by incloud processes. Information on the hygroscopicity provides particle growth factors necessary to calculate the particle water content in order to assess the mass balance. At the summit, in addition to the applied methods outlined above for the characterisation of cloud drops, the LWC of the cloud and the size distribution of cloud droplets were determined with optical instruments. The location of the cloud base was determined at the upwind site. Both the liquid water content and the cloud base height were important parameters to asses the suitability of the cloud event for further measurements.

\subsubsection{Particle sampling}

Berner impactors were used for the collection of sizesegregated particles. Particles were also collected on filters in the $\mathrm{PM}_{1}, \mathrm{PM}_{2.5}$ and $\mathrm{PM}_{10}$ size categories, so as to enable comparison with samples obtained by other techniques, and to provide sufficient material for chemical analysis, especially of organic compounds. In 
Table 3

Scientific measurements at all sites and responsibilities of participating groups

\begin{tabular}{|c|c|c|c|c|}
\hline Measurement & Goldlauter (U) & Schmücke (C) & Gehlberg (D) & Method* \\
\hline \multicolumn{5}{|l|}{ Meteorology } \\
\hline $\begin{array}{l}\mathrm{T} \text {, r.h., wind speed \& direction, } \mathrm{J}\left(\mathrm{NO}_{2}\right) \text {, } \\
\text { global radiation, pressure, precipitation }\end{array}$ & BTU & DWD/IfT & IfT & Automatic weather station \\
\hline \multicolumn{5}{|l|}{ Gas phase measurements } \\
\hline $\mathrm{O}_{3}$ & BTU & UBA & IfT & UV absorption \\
\hline $\mathrm{SO}_{2}$ & BTU & UBA & IfT & UV fluorescence \\
\hline $\mathrm{NO}$ & BTU & UBA & If T & Chemiluminescence + PLC \\
\hline $\mathrm{NO}_{2}$ & BTU & UBA & IfT & Chemiluminescence + PLC \\
\hline NOy & BTU & - & - & Gold-converter + chemiluminescence \\
\hline $\mathrm{NOz}$ & BTU & - & - & \\
\hline $\mathrm{H}_{2} \mathrm{O}_{2}$ & BTU/ZUF & ZUF & ZUF & enzymatic fluoresc., HPLC \\
\hline $\mathrm{CO}$ & IfT & IfT & If T & Gas filter correlation - IR \\
\hline NMHC & IfT/UBA & - & - & GC-FID \\
\hline Carbonyl compounds & TUD/IfT & IfT & TUD/IfT & GC / HPLC \\
\hline Organic acids & TUD & & TUD & Spray collector - GC \\
\hline $\mathrm{HNO}_{2}$ & BTU & - & - & Denuder - IC \\
\hline $\mathrm{HNO}_{3}$ & BTU & - & - & Denuder - IC \\
\hline $\mathrm{HCl}$ & BTU & - & - & Denuder - IC \\
\hline \multicolumn{5}{|l|}{ Aerosol and cloud physics } \\
\hline Number size distribution & IfT & IfT & IfT & TDMPS \\
\hline \multicolumn{5}{|l|}{ Coarse: $20-900 \mathrm{~nm}$ Fine: $3-22 \mathrm{~nm}$} \\
\hline Droplet residuals, interstitial particles & - & IfT & - & CVI + DMPS INT + DMPS \\
\hline Hygroscopicity & IfT & - & - & HDMPS \\
\hline LWC & - & IfT/BTU & - & Gerber PVM 100 \\
\hline Size distribution (cloud droplets) & - & ZUF/BTU & - & FSSP \\
\hline Cloud base height & BTU & - & - & Vaisala CTK25 Ceilometer \\
\hline Tracer experiment & ZUF & ZUF & ZUF & $\mathrm{SF}_{6}-\mathrm{GC}-\mathrm{ECD}$ \\
\hline
\end{tabular}


QF-Filter $\mathrm{PM}_{1} \mathrm{HV}$

LV-acidic components

Interstitial particles, $\mathrm{CCN}$

Particle analysis

Mass IfT

Ions

$\mathrm{OC} / \mathrm{EC}$

Metals (Fe, $\mathrm{Cu}, \mathrm{Mn}, \mathrm{Zn}$ )

$\mathrm{BC}$ in $\mathrm{CCN} \&$ interst. particles

Semivol. organic comp.

Cloud water

Size dependent sampling

Bulk sampling

$\mathrm{pH}$

Conductivity

Ions

Organic acids

$\mathrm{H}_{2} \mathrm{O}_{2}$

WSOC (TOC)

$\mathrm{OC} / \mathrm{EC}$

Carbonyl compounds
IfT

\section{BTU/IfT}

IfT

IfT

IfT

$-$

-

-

-

-

-

-
-

-

$-$

IfT

-

IfT
IfT

IfT

IfT

IfT

BTU/ZUF/CSU

BTU/IfT

ZUF

ZUF

IfT/BTU

IfT/TUD

ZUF

IfT/BTU/CSU

IfT (CSU)

TUD/CSU
IfT

IfT

\section{IfT}

IfT

IfT

IfT

IfT

-
-
-
-
-
-
5-stage-Berner (r.h.-60\%)

Sierra-Andersen- HV $\left(1 \mathrm{~m}^{3} / \mathrm{min}\right)$

Digitel DHA-80 (500 1/min)

Digitel DHA-80 (300 l/min)

Denuder-Steamjet

Polycarbonate \& quartz filter

UMT 2 (Mettler)

IC, CE

Thermography + NDIR

AAS

PSAP

GC-MS, LC-MS

CSU, BSE;

Mettler 405-60 88TE-S7/120

WTW, LDM/S 2908/06 11.83.

IC (Metrohm,Dionex), CE (TS)

CE (TS)/ GC (Agilent)

NDIR; Shimadzu TOC 5000A

NDIR; Shimadzu TOC 5000A

GC

*Details on the methods applied are reported in the single contributions of this special issue. 
Table 4

Analysers for trace gas analysis at the three experiment sites and their properties

\begin{tabular}{llcc}
\hline Gas analyser (site) & Technique & $\begin{array}{l}\text { Detection limit } \\
\text { (ppbv) }\end{array}$ & $\begin{array}{c}\text { Time resolution } \\
T_{95}(\mathrm{~min})\end{array}$ \\
\hline CO MLU 300 (U) & & 50 & $<0.7$ \\
CO Ansyco CO11 M (S) & IR-absorption & 100 & $<0.7$ \\
CO TE 48C (S) & IR-absorption & 100 & $<0.7$ \\
$\mathrm{CO}$ ML 9830 (D) & IR-absorption & 100 & $<0.7$ \\
$\mathrm{O}_{3}$ Dasibi 1108 (U) & IR-absorption & 1 & $<2$ \\
$\mathrm{O}_{3}$ APOA 350E (S) & UV-absorption & 1 & $<2$ \\
$\mathrm{O}_{3}$ TE 49 C (D) & UV-absorption & 1 & $<2$ \\
$\mathrm{SO}_{2}$ TE 43 C TL(U) & UV-absorption & $<2$ \\
$\mathrm{SO}_{2}$ TE 43 C (S) & UV-fluorescence & 0.1 & $<2$ \\
$\mathrm{SO}_{2}$ TE 43 C-TL (D) & UV-fluorescence & 1 & $<2$ \\
$\mathrm{NO}_{x}$ Ecophysics CLD & UV-fluorescence & 0.1 & 0.5 \\
770 ppt \& PLC (U) & Chemiluminescence & 0.05 & \\
$\mathrm{NO}_{x}$ TE 42 C (S) & & & 0.5 \\
$\mathrm{NO}_{x}$ ML 9841 A (D) & Photolytic converter & 1 & 0.5 \\
$\mathrm{NO}_{y}$ Ecophysics CLD 770 ppt (U) & Chemiluminescence & 0.5 & 0.5 \\
\hline
\end{tabular}

Table 5

Aerosol samplers in use at the three sites of investigation

\begin{tabular}{|c|c|c|}
\hline Aerosol sampler & Size range & Volume flow $\left(1 \mathrm{~min}^{-1}\right)$ \\
\hline Berner impactor (five stages) & $0.05 / 0.14 / 0.42 / 1.2 / 3.5 / 10 \mu \mathrm{m}$ & 75 \\
\hline Sierra-Andersen HVS & $\mathrm{PM}_{10}$ & 1000 \\
\hline Digitel DHA-80 & $\mathrm{PM}_{2.5}$ & 500 \\
\hline Digitel DHA-80 & $\mathrm{PM}_{1}$ & 300 \\
\hline $2 \mathrm{CVI}$ in parallel for $\mathrm{CCN}^{\mathrm{a}}$ & $5-50 \mu \mathrm{m}$ & $2 * 8$ \\
\hline INT for interstitial particles & $<5 \mu \mathrm{m}$ & 60 \\
\hline
\end{tabular}

$\mathrm{PM}_{1}$ : particulate matter less than $1 \mu \mathrm{m}$ in diameter.

$\mathrm{PM}_{2.5}$ : particulate matter less than $2.5 \mu \mathrm{m}$ in diameter.

$\mathrm{PM}_{10}$ : particulate matter less than $10 \mu \mathrm{m}$ in diameter.

${ }^{\mathrm{a}}$ Enrichment factor between 5 and 10 possible.

addition, the denuder - steam jet technique was used at the upwind site for the purpose of comparison, because it avoids sampling artefacts.

\subsubsection{Chemical analysis of particles}

The chemical analysis of the particle samples was carried out (i) from filters, (ii) from the denuder-steamjet combination and (iii) in a size-segregated manner from Berner impactors for the main ionic components, the sum parameters OC/EC (OC, organic carbon; EC, elemental carbon) as well as for individual organic compounds. Mass closure was performed in a sizesegregated manner (for details see Gnauk et al., 2005; Müller et al., 2005).

\subsubsection{Cloud water}

Cloud water was sampled using cloud water sampler of different design and analysed like particles extended by hydrogen peroxide, carbonyl compounds, and water soluble organic carbon (WSOC), also called total organic carbon (TOC) as sum of dissolved organic carbon (DOC) and particulate organic carbon (POC).

\subsubsection{Quality control}

The instruments used for standard trace gases were provided by UBA, BTU and IfT. Quality control was assured by means of intercomparison tests performed by the BTU group. The BTU instruments, in turn, were calibrated prior to the measurement campaign using a mobile calibration system kindly provided by the IFU Institute at Garmisch-Partenkirchen. The calibration of this system is traceable to primary US NIST standards. The intercomparison of instruments included a five point calibration in the range $0-100 \mathrm{nmol} \mathrm{mol}^{-1}$ (ppb) for each $\mathrm{NO}_{x}, \mathrm{O}_{3}$ and $\mathrm{SO}_{2}$, followed by ambient air measurements over a $24 \mathrm{~h}$ period. Calibration gases 
during the campaign were provided by an Environics S 100 calibrator, which also included an ozone generator. Zero air was produced by an Ecophysics Pure Air Generator, which was also used for daily calibration checks.

Particle counting systems were calibrated in different ways. The differential mobility analysers that were used either directly or in conjunction with counter-flow virtual impactors and the detection of interstitial particles were calibrated against each other before each measurement campaign. The efficiency of the condensation particle counters (CPCs) was determined during a WMO calibration workshop organised at the IfT after the second measurement campaign. The collection efficiency of the devices used for collecting particles (Berner impactor, filters, etc.) was determined during an international collector comparison study at the research station Melpitz of the IfT (INTERCOM2000, ten Brink et al., 2004; Müller et al., 2004). The sampling efficiency of the cloud water collectors was checked by comparing the cloud water volume sampled with that determined with the Gerber PVM 100 instrument.

The determination of the mass of collected particles was accomplished by weighing with a high-precision microbalance calibrated twice annually. The foils on which the particles were deposited were treated with deionised water so as to condition the surface, before the first and final weighing was performed at $50 \%$ r.h. and $22{ }^{\circ} \mathrm{C}$. The masses of the deposits collected by different sampling devices were compared with each other. The deposits on the individual stages of the Berner impactor were included in the comparison as well as the mass of aerosol particles calculated from the number concentration (Gnauk et al., 2005).

The procedures used for chemical analysis were subjected to regular internal quality assurance tests, which include storage and transport of samples frozen to $-18^{\circ} \mathrm{C}$, determination of blanks and control of standard deviations from the mean. During the past 10 years the analytical laboratories of BTU and IfT have successfully taken part in international intercomparison tests organised twice annually by the WMO for the main inorganic components. The methods used to determine organic carbon and elemental carbon were subjected to quality assurance tests by participating in round robin tests organised by the Technical University in Vienna. In addition, duplicate samples were taken and measured for comparison by two of the participating groups (inorganic components: BTU and IfT, organic components: TUD and IfT).

\subsection{Measurement regime}

A number of specific conditions are required for the measurements: These include a wind direction from the south-west $\left(210-250^{\circ}\right.$ sector), and a wind speed at the Schmücke summit of at least $5 \mathrm{~m} \mathrm{~s}^{-1}$ and not exceeding
$12 \mathrm{~m} \mathrm{~s}^{-1}$. Only in this range of wind direction and wind speed the air mass flow can be expected to follow trajectories connecting the three stations (see the contribution of Heinold et al., 2005). If the wind speed is too low, local emission and deposition processes will have a dominant influence on the composition of the air, whereas at wind speeds beyond the indicated range safety rules disallow personnel to be on the tower. Weather forecasts by the DWD and a daily synopsis were used to asses the situation and come to a decision on whether measurements should be performed or not. A second condition required the presence of a cloud at the Schmücke summit with liquid water content greater than $0.1 \mathrm{~g} \mathrm{~m}^{-3}$, while at the same time both upwind station and downwind station hat to be free of clouds. A third condition was that none of the three sites was expected to experience any precipitation. These conditions were met on 17 days in the year 2001 and on 13 days in 2002. In some cases, several shorter measurement periods were combined. Particle collection by impactors required at least $6 \mathrm{~h}$ to obtain sufficient material for chemical analysis. In the year 2001, the experiments permitted nine such samples to be obtained, while in 2002 altogether five samples were collected during the individual sampling periods.

\section{Results and discussion}

\subsection{Selection of suitable measurement periods}

Before and during the first experiment tracer experiments were carried out to define the trajectory of the air flow between the three measurement sites. The results of these experiments helped to define the boundaries of the dispersion model used to describe the air flow over the mountain ridge. Both tracer experiments and dispersion model are presented in Heinold et al. (2005).

Meteorological conditions were assessed by synoptic analysis based on satellite images, two radio soundings per day from Meiningen (about $30 \mathrm{~km}$ distance from the summit) and local meteorological observations by the German Weather Service at the Schmücke. A detailed overview of the meteorological situation during the FEBUKO measurement periods is given by Tilgner et al. (2005a). From the meteorological situation and the air flow characteristics described by Tilgner et al. (2005a) and Heinold et al. (2005) the three best cloud events were identified and these data were used for the further analysis. They are labelled EI, EII, and EIII. The key data for the selected measurement periods are summarised in Table 1.

\subsection{A consideration on entrainment indicators}

For comparison with data in the literature for former hill-capped cloud experiments, an effort was made to 
collect and summarise the indicators for the entrainment of outside air into the air flow during its trajectory from Goldlauter via the Schmücke to Gehlberg. These indicators are summarised in Table 6. In agreement with the criteria suggested by Colvile et al. (1997) such as the conservation of gas phase and particle phase tracers, the agreement of the measured cloud LWC with the adiabatic LWC and the cloud droplet size distribution characteristics, the observations generally support the conclusion that no significant entrainment occurred during the three measurement periods selected for detailed analysis. However, the detailed model that includes the micro-physics as described in the contribution of Simmel et al. (2005) indicates that entrainment may have been possible as it would possible explain differences observed between the cloud physical measurements and model predictions, especially with regard to the liquid water content. Thus, the degree of entrainment at event EI is small, that during event EII may be larger and that the event EIII maybe larger still, Nevertheless, all three events are characterised by a connected air mass flow from the upwind station via the summit toward the downwind station.

\subsection{Main findings from physical measurements}

The hygroscopic growth of particles with diameters 50,150 and $250 \mathrm{~nm}$ was measured at $90 \%$ relative humidity with a hygroscopicity-tandem differential mobility analyser. The results are discussed by Lehmann et al. (2005). At least two types of particles with differing growth behaviour were found: one group was nearly hydrophobic, the other was quite hygroscopic. A simple growth model was applied based on the assumption that the soluble volume fraction consists of ammonium sulphate. Thereby the distributions of the soluble volume fraction were derived. The distributions for 150 and $250 \mathrm{~nm}$ particles were bimodal. One peak occurred below $\varepsilon=0.2$, showed a minimum in the range $0.2<\varepsilon<0.4$ and a second maximum at $\varepsilon>0.4$. The hygroscopic growth of the particles at $50 \mathrm{~nm}$ differed from that of the larger particles in that sometimes more than two growth modes with different hygroscopicities were present. This makes the specification of a growth factor problematic (see Lehmann et al., 2005, for details). The distribution of soluble volume for the $50 \mathrm{~nm}$ particles peaked at $\varepsilon<0.3$. The influence of the distribution of soluble volume fraction on the activation of aerosol particles to form cloud drops is analysed by Mertes et al. (2005a). The fraction of particles acting as cloud condensation nuclei depends critically on both the soluble volume fraction of the particles and the particle diameter. A strong correlation was found between the increase of soluble volume fraction with the size of the particles and the fraction of particles that become scavenged to form cloud drops. On the other hand, the interstitial aerosol contained particles that according the Köhler theory should have been formed cloud drops but did not, possibly due to the presence of a hydrophobic organic surface coating. The generation of additional mass in the cloud was observed in the particle diameter range $60-300 \mathrm{~nm}$. This is described by Mertes et al. (2005b). The mass gain is mainly attributed to the oxidation of $\mathrm{SO}_{2}$ and the uptake of $\mathrm{NH}_{3}$, although the formation of organic non-volatile compounds cannot be ruled out. Mertes et al. (2005b) have also observed the nighttime production of ultra-fine particles in the outflow of the orographic cloud.

\subsection{Main findings from sampling method intercomparison}

A variety of devices were used for the collection of particles and cloud water during the campaign. This permitted a comparison of the different methods. The results are reported by Gnauk et al. (2005), Müller et al. (2005), Wieprecht et al. (2005) and Brüggemann et al. (2005). High-volume filters and low pressure impactors may be subject to positive or negative artefacts, which are revealed by the differences of results. For nonvolatile components, such as sulphate, similar results were obtained, whereas the more volatile components, such as nitrate and ammonium, frequently experienced losses when they were collected by impactors. The steamjet technique, which avoids these problems but cannot differentiate between particle sizes, resulted in higher concentrations that agreed well with the concentrations observed for cloud water. Therefore, concentrations obtained by the steamjet technique were used to correct the size-segregated concentrations derived from the impactors. Organic mono- and dicarboxylic acids that were collected by scrubbers, showed significant differences by factors up to 2-3 in the concentrations of some analytes compared with samples from high-volume filter and impactors, but no obvious trend. The various methods used to collect cloud water resulted in efficiencies ranging from $45 \%$ to $79 \%$. However, the concentrations of analytes differed only by $10 \%$, on average.

\subsection{Main findings from chemical measurements}

A complex data set consisting of gas, liquid and sizesegregated particle phase component concentrations, meteorological, and cloud physics data was provided from field measurements to investigate the effects of incloud processes on changes in the chemical composition of particles during cloud passage. The upwind site part of the data set was used for the initialisation of the applied SPACCIM model on a realistic basis.

The $\mathrm{PM}_{10}$ mass concentrations fell in the range $8-17 \mu \mathrm{g} \mathrm{m}^{-3}$. The major ionic species, sulphate, nitrate 
Table 6

Overview on indicators for entrainment during the FEBUKO events

\begin{tabular}{|c|c|c|c|c|c|c|c|}
\hline & Remarks & \multicolumn{2}{|c|}{$\begin{array}{l}\text { Event EI } \\
26-27 \text { October } 2001\end{array}$} & \multicolumn{2}{|l|}{$\begin{array}{l}\text { Event EII } \\
06-08 \text { October } 2001\end{array}$} & \multicolumn{2}{|c|}{$\begin{array}{l}\text { Event EIII } \\
\text { 16-17 October } 2002 \\
17: 00-04: 10\end{array}$} \\
\hline Potassium $\left(\mathrm{K}^{+}\right)^{(\mathrm{f})}$ & 1 & Constant $^{(\mathrm{c})}$ & Constant & $24 \%$ Loss & Constant & $20 \%$ loss & Constant \\
\hline Sulphate $\left(\mathrm{SO}_{4}^{2-}\right)^{(\mathrm{f})}$ & 1 & $23 \%$ Increase & $21 \%$ Loss & Constant & Constant & $20 \%$ loss & Constant \\
\hline Elemental carbon $(\mathrm{EC})^{(\mathrm{g})}$ & 1 & Constant & $27 \%$ Loss & $100 \%$ Increase & $70 \%$ Loss & Constant & $47 \%$ loss \\
\hline $\begin{array}{l}\text { Oxalate } \\
\left(\mathrm{HOOC}^{-\mathrm{COO}^{-}}\right)^{(\mathrm{g})}\end{array}$ & 2 & Constant & Constant & Constant $^{\text {h }}$ & $10 \% \operatorname{loss}^{\mathrm{h}}$ & Constant & Constant \\
\hline Malonate $\left(\mathrm{HOOC}-\mathrm{CH}_{2}-\mathrm{COO}^{-}\right)^{(\mathrm{g})}$ & 2 & Constant & $14 \%$ Loss & $19 \%$ Increase $^{\mathrm{h}}$ & $18 \% \operatorname{loss}^{\mathrm{h}}$ & $19 \%$ loss & Constant \\
\hline $\begin{array}{l}\text { Summary for chemical particle } \\
\text { tracers }\end{array}$ & & Constant & Constant/Loss & Constant & Constant/Loss & Constant/Loss & Constant \\
\hline Particles with $25<D_{\mathrm{p}}<60 \mathrm{~nm}$ & 4 & Identical & Identical & Slight shift to smaller sizes & $\begin{array}{l}\text { Identical shape, little smaller } \\
\text { concentration }\end{array}$ & $\begin{array}{l}\text { Identical shape, } \\
\text { little smaller } \\
\text { concentration }\end{array}$ & $\begin{array}{l}\text { Identical shape, little smaller } \\
\text { concentration }\end{array}$ \\
\hline Ozone & 6 & $\begin{array}{l}\text { Minor differen } \\
\text { middle of even }\end{array}$ & ecially in the & Approximately the same at & sites & $\begin{array}{l}\text { Approximately th } \\
\text { at D }\end{array}$ & same between $\mathrm{U}$ and $\mathrm{C}$; greater \\
\hline $\begin{array}{l}\text { Cloud } \mathrm{LWC}^{(\mathrm{d})} \text { range; mean } \pm 1 \sigma \\
{\left[\mathrm{g} \mathrm{m}^{-3}\right]}\end{array}$ & 5 & $0.129-0.551 ; 0$. & .097 & $0.002-0.524 ; 0.203 \pm 0.104$ & & $0.024-0.417,0.20$ & \pm 0.052 \\
\hline LWC from DWD-LM $\left[\mathrm{g} \mathrm{m}^{-3}\right]$ & 6 & $0.1-0.3$ (mean: & & $\begin{array}{l}0.0 \text { (mean: } 0.0 \text { ) } \\
0.0-0.2 \text { (mean: } 0.1) \\
0.0-0.4 \text { (mean: } 0.2 \text { ) }\end{array}$ & & $0.3-0.4$ (mean: 0 . & \\
\hline Cloud LWC compared to adiabatic & 5 & $29 \%$ Subadiab & & $42 \%$ Subadiabatic & & $31 \%$ subadiabati & \\
\hline Correlation LWC $=\mathrm{f}\left(\mathrm{CBH}^{(\mathrm{d})}\right)$ & 5 & Moderate/strol & -0.85 & Moderate, $r=-0.75$ & & Moderate, $r=-$ & \\
\hline $\begin{array}{l}\text { Cloud top height } \\
\text { (m agl) from DWD-LM }\end{array}$ & 6 & $300-1100$ (mea & & $\begin{array}{l}1000-1100 \text { (mean: } 1075) \\
450 \\
200-1000 \text { (mean: } 420)\end{array}$ & & 1500-2100 (mean & 2000) \\
\hline Mean Richardson number & 6 & 1.77 & & 1.1 & & 0.5 & \\
\hline Thermal stratification, wind shear & 3.6 & Stable, slight & & Stable-neutral, slight & & Less stable, stron & \\
\hline Cloud droplet size distribution modes & 5 & Monomodal & & Monomodal & & Monomodal & \\
\hline $\begin{array}{l}\text { Activation of particles with } \\
D_{\mathrm{p}}>500 \mathrm{~nm}\end{array}$ & 4 & $96 \%$ & & $91 \%$ & & $94 \%$ & \\
\hline $\begin{array}{l}\text { Indication for effects of entrainment } \\
\text { through modelling for }\end{array}$ & 7 & & & & & & \\
\hline (i) Cloud LWC & 7 & Weak to mode & & Moderate to strong & & Weak to modera & \\
\hline (ii) Cloud droplet size distributions & 7 & Weak & & Weak & & Very strong & \\
\hline $\begin{array}{l}\text { (iii) Cloud droplet number } \\
\text { concentration }\end{array}$ & 7 & Weak & & Weak & & Weak & \\
\hline
\end{tabular}

(1) See Gnauk et al. (2005) and Brüggemann et al., this issue (2005), (2) See van Pinxteren et al., this issue (2005), (3) See Tilgner et al. this issue (2005a), (4) See Mertes et al. this issue (2005a), (5) See Wieprecht et al. this issue (2005), (6) See Heinold et al. this issue (2005), (7) See Simmel et al. this issue (2005).

(a) Part 1: 06 October 2001, 10:30-14:15, part 2: 07 October 2001, 13:15-15:15, part 3: 07 October-08 October 18:00-11:00, (b) U: upwind station Goldlauter, S: cloud station Schmücke, D: downwind station Gehlberg, (c) constant = changes no bigger than $\pm 10 \%$, (d) LWC $=$ liquid water content, (e) CBH $=$ cloud base height, (f) particles sampled by high volume Andersen filter sampler, (g) particles sampled by BERNER impactor, (h) data from part 3 of event EII only, cp. (a). 
and ammonium, amounted to $90 \%$ of the total. The concentration of carbonaceous material differed, depending on the origin of the air mass. In event EI, where the origin was continental, the concentration amounted to $19 \%$ of total mass. In EII and EIII, where the air mass had a marine origin, the fraction was $33 \%$ of total mass. In these cases, the ratio of the total organic fraction to that of elemental carbon were about 2.5. In air masses of continental origin the ratio was 1.1. The mass concentration of particles ranging in size up to $900 \mathrm{~nm}$, which was derived from differential mobility measurements, agreed well with that determined by weighing. The chemical mass balance also was in good agreement with the total mass obtained by weighing. $<10-30 \%$ of the material was remained unidentified.

The concentrations of dicarboxylic acids were low at night and arose during the day until noon (in EI and EII) by a factor of 2-5. The concentration of carboxylic acids decreased with increasing carbon number. The maximum concentration occurred in the size range of $0.42-1.2 \mu \mathrm{m}$ (diameter), where most of particulate mass is concentrated. The gas phase mixing ratios of many carbonyl compounds as formic acid and acetic acid displayed a similar diurnal variation in concentration. Particulate organic compounds of biogenic origin, such as levoglucosan and xylitole occurred with significant concentrations $\left(100 \mathrm{ng} \mathrm{m}^{-3}\right)$ in the same size range as oxalic acid, whereas the concentrations of pinic acid and pinonic acid were very low $\left(0.5-2.6 \mathrm{ng} \mathrm{m}^{-3}\right)$.

The concentrations of non-volatile species such as sulphate and elemental carbon were essentially the same in the particle phase and in cloud water, although the concentrations of volatile components, such as nitrate, ammonium and organic carbon, were lower at the upwind site. The increase of particulate concentrations between the upwind and the downwind site occurred primarily in the smallest size range $\left(0.05<D_{\mathrm{p}}<0.14 \mu \mathrm{m}\right)$. During the event EI, sulphate increased by $20 \%$ and ammonium by $17 \%$, during the event EIII the percentage increase was $70 \%$ and $150 \%$, respectively. The concentration of organic carbon was found to increase by $20 \%$ in the size range $0.14<D_{\mathrm{p}}<0.42$. These effects indicate accumulation of material by in-cloud reactions. Unambiguous evidence for an increase in concentration in the accumulation mode of the aerosol size distribution was obtained for the event EIII. This observation and the results of chemical analysis were confirmed by model calculations.

A greater number of soluble organic species were found in cloud water and their time dependence was determined. Carbonyl compounds and carboxylic acids contributed $10-17 \%$, on average, to the organic fraction. Several organic compounds were here observed for the first time: glycolaldehyde, pinonaldehyde, butyric acid, malic acid and pinic acid. The budgets of organic compounds on their way through the cloud indicated a source of acetic acid.

Also some dicarboxylic acids, e.g. malonic acid, were found in slightly higher relative abundance at the downwind station, at least for some of the investigated particle size ranges. These effects may potentially be attributed to in-cloud processing of the aerosol.

\subsection{Main results from model development and application}

The parcel model SPACCIM which combines a complex multiphase chemistry with detailed microphysics has been developed (Wolke et al., 2005) treating a highly size-resolved drop spectrum applying adapted numerical algorithms and implicit time integration methods which integrate all involved processes in a coupled manner and utilise the special structure of large sparse equation systems (Sehili et al., 2005; Simmel et al., 2005).

In the SPACCIM approach, a new coupling scheme between microphysical and multiphase chemical models is implemented. The two codes run separately as far as possible and exchange all information needed at defined times. This approach allows the coupling of a complex multiphase chemistry model with microphysical codes of various types. Two adiabatic air parcel models (Simmel and Wurzler, 2005) with detailed microphysics and interactions between aerosol particles and drops are employed for SPACCIM simulations: one with traditional 1D treatment of the microphysics (water mass only) and one with a two-component treatment of the microphysics (water and aerosol mass). The latter allows drops of the same size to have different aerosol mass contents and, therefore, different gas scavenging properties (Sehili et al., 2005). In the "fully coupled" approach of Knoth (2005), the model equations for the microphysical variables (temperature, water vapour, liquid water content) as well as for all chemical species are considered as one system which is integrated in a coupled manner by an implicit-explicit time integration scheme. Therefore, no splitting error between microphysics and multiphase occurs. The model is based on the discretisation in mass space of the multi-component general dynamic equation using the Discrete Galerkin Method. Finally, a model intercomparison figure out discrepancies as well as similarities between different approaches for the coupled simulation of microphysical and multiphase chemical processes (Sehili et al., 2005).

A new version of CAPRAM has been developed which provides a better description of tropospheric multiphase chemistry of higher organics (Herrmann et al., 2005). The use of very complex multiphase reaction schemes in higher dimensional models is restricted due to the computational burden. Therefore, the application of tools for the reduction of chemical 
reaction mechanisms is important. The automated reduction method ISSA ("Iterative Screening and Structure Analysis") of Mauersberger (2005) achieves a good performance in this context. An application of the ISSA method to the cloud chemical mechanism RACM/ CAPRAM 2.4 (Ervens et al., 2003) results in reduction rates of $55 \%$ for reactions ( $46 \%$ gas phase, $60 \%$ liquid phase), $23 \%$ for species, and $23 \%$ for phase transfers. Certainly, this reduction will also be applied to CAPRAM 3.0 in the future. An advanced treatment of the description of cloud boundaries has been put forward by the application of the VOF ("Volume of Fluid") method by Hinneburg and Knoth (2005).

By means of the Lagrangian model SPACCIM, simulations of the hill cap cloud passage experiment FEBUKO were carried out (Tilgner et al., 2005b). Simulations were performed with an air parcel travelling along a predefined trajectory from upwind site through the orographic cloud to downwind site. For the description of the chemical reactions in the atmospheric multiphase system, CAPRAM 3.0 (Herrmann et al., 2005) was applied. The complex data set obtained in the FEBUKO field experiments was of huge importance for the MODMEP model initialisation and validation. Furthermore, the SPACCIM simulations were used for the interpretation of the measurements and allow a better understanding of cloud events effects on the physico-chemical properties of the atmospheric aerosols.

The modelling studies have been shown the importance of dynamic microphysical processes on multiphase chemistry. For all treated events, a significant cloud condensation nuclei $(\mathrm{CCN})$ modification with sizes up to about $400 \mathrm{~nm}$, mass productions up to about $0.7 \mu \mathrm{g} \mathrm{m}^{-3}$ and acidification caused by cloud processing were identified in the model in agreement with the experimental findings. Final extensive comparisons between modelled and measured concentrations at both sites have been shown to be in good agreements. However, for organic compounds with low solubilities several cloud water measurements show considerably higher concentrations as expected from both (i) their Henry solubilities (van Pinxteren et al., 2005) and (ii) the complex multiphase modelling as performed by SPACCIM. These facts indicated that less soluble organic tropospheric trace gases e.g. aldehydes might potentially be adsorbed on surfaces of cloud droplets and possibly on deliquescent aerosol particles. For that reason, future multiphase chemistry models will include a description of surface layer chemistry as well as heterogeneous reactions. But for all that, the combination of SPACCIM and CAPRAM have been finally allowed an adequate prognosis of cloud water as well as aerosol concentrations of a variety of inorganic and, for the first time, also of a number of organic compounds with up to four carbon atoms during the cloud passage of an air parcel.

\section{Summary}

The main findings from the coupled FEBUKO and MODMEP projects are to be shortly summarised here. Firstly, the FEBUKO field site Schmücke has been characterised in much detail and it has been demonstrated that connected flow conditions can be observed and verified by tracer experiments and flow models. Great care has to be taken in order to obtain a realistic picture of chemical particle composition including cloud water composition. The coupling of size-resolved sampling and complementary non-size-resolved sampling techniques is urgently required. It is highly desirable to step into the development of real-time or near-real-time particle characterisation techniques especially for cloud processing experiments.

Much more work is required to the individual chemical species in the organic carbon fraction of particles, where about $15 \%$ of the organic mass could be accounted for in FEBUKO. Upon activation of particles, budget has been considered and shows good agreement between the upwind and the cloud station in many cases. An important finding is that cloud droplets do contain much more organic compounds then expected from their Henry-solubility and this difference becomes bigger for less soluble species. The same applies for the comparison of measurements and SPACCIM results. A better model picture appears to be required here, e.g. introducing a third reservoir consisting of species absorbed at the droplets surfaces.

During FEBUKO, clearly mass increases for the particles being processed by clouds could be identified under connected flow conditions as averages over observation times of several hours much more extensive than in the material available hitherto. The changes in the experimentally determined aerosol size distributions can be well reproduced by the SPACCIM model. The model results indicate complex interaction of soluble gases and particle constituents the coverage of which even in CAPRAM 3.0 is still far from complete.

\section{Acknowledgements}

FEBUKO and MODMEP have been performed within the AFO 2000 research programme of the German Bundesministerium für Bildung und Forschung. Financial support is gratefully acknowledged under FK 07ATF01 (FEBUKO) and FK 07ATF40 (MODMEP). We would like to thank the reviewers of this contribution for their helpful comments.

\section{References}

Audiffren, N., Renard, M., Buisson, E., Chaumerliac, N., 1998. Deviation from the Henry's law equilibrium during cloud 
events: a numerical approach of the mass transfer between phases and its specific numerical effects. Atmospheric Research 49, 139-161.

Bott, A., 1999. A numerical model of the cloud-topped planetary boundary layer: chemistry in marine stratus and the effects on aerosol particles. Atmospheric Environment 33, 1921-1936.

Bower, K.N., Choularton, T.W., Gallagher, M.W., Colvile, R.N., Beswick, K.M., Inglis, D.W.F., Bradbury, C., Martinsson, B.G., Swietlicki, E., Berg, O.H., Cederfelt, S.I., Frank, G., Zhou, J., Cape, J.N., Sutton, M.A., McFayden, G.G., Milford, C., Birmili, W., Yuskiewicz, B.A., Wiedensohler, A., Stratmann, F., Wendisch, M., Berner, A., Ctyroky, P., Galambos, Z., Mesfin, S.H., Dusek, U., Dore, C.J., Lee, D.S., Pepler, S.A., Bizjeak, M., Diviak, B., 1999. The Great Dun Fell Experiment 1995: an overview. Atmospheric Research 50, 151-184.

Brüggemann, E., Gnauk, T., Mertes, S., Acker, K., Auel, R., Wieprecht, W., Möller, D., Collett Jr., J.L., Chemnitzer, R., Rüd, C., Junek, R., Herrmann, H., 2005. Schmücke hill cap cloud and valley stations aerosol characterisation during FEBUKO (I): particle size distribution and main components. Atmospheric Environment (this issue).

Choularton, T.W., Colvile, R.N., Bower, K.N., Gallagher, M.W., Wells, M., Beswick, K.M., Arends, B.G., Möls, J.J., Kos, G.P.A., Fuzzi, S., Lind, J.A., Orsi, G., Facchini, M.C., Laj, P., Gieray, R., Wieser, P., Engelhardt, T., Berner, A., Kruisz, C., Möller, D., Acker, K., Wieprecht, W., Lüttke, J., Levsen, K., Bizjak, M., Hansson, H.-C., Cederfelt, S.-I., Frank, G., Mentes, B., Martinsson, B., Orsini, D., Svenningsson, B., Swietlicki, E., Wiedensohler, A., Noone, K.J., Pahl, S., Winkler, P., Seyffer, E., Helas, G., Jaeschke, W., Georgii, H.W., Wobrock, W., Preiss, M., Maser, R., Schell, D., Dollard, G., Jones, B., Davies, T., Sedlak, D.L., David, M.M., Wendisch, M., Cape, J.N., Hargreaves, H.J., Sutton, M.A., Storeton-West, R.L., Fowler, D., Hallberg, A., Harrison, M., Peak, J.D., 1997. The Great Dunn Fell Experiment 1993: an overview. Atmospheric Environment 31, 2393-2405.

Collett Jr., J.L., Bator, A., Sherman, D.E., Moore, K.F., Hoag, K.J., Demoz, B.B., Rao, X., Reilly, J.E., 2002. The chemical composition of fogs and intercepted clouds in the United States. Atmospheric Research 64, 29-40.

Colvile, R.N., Bower, K.N., Choularton, T.W., Gallagher, M.W., Wobrock, W., Hargreaves, K.J., Storeton-West, R.L., Cape, J.N., Jones, B., Wiedensohler, A., Hansson, H.C., Wendisch, M., Acker, K., Wieprecht, W., Pahl, S., Winkler, P., Berner, A., Kruisz, C., 1997. Meteorology of the Great Dun Fell cloud experiment 1993. Atmospheric Environment 31 (16), 2407-2420.

Djouad, R., Michelangeli, D.V., Gong, W., 2003. Numerical solution for atmospheric multiphase models: testing the validity of equilibrium assumptions. Journal of Geophysical Research 108 (D19), 4602-4614.

Ervens, B., George, C., Williams, J.E., Buxton, G.V., Salmon, G.A., Bydder, M., Wilkinson, F., Dentener, F., Mirabel, P., Wolke, R., Herrmann, H., 2003. CAPRAM2.4 (MODAC mechanism): an extended and condensed tropospheric aqueous phase mechanism and its application. Journal of Geophysical Research 108 (D14), 4426.
Fahey, K.M., Pandis, S.N., 2001. Optimizing model performance: variable size resolution in cloud chemistry modeling. Atmospheric Environment 35, 4471-4478.

Feingold, G., Kreidenweis, S.M., 2000. Does cloud processing of aerosol enhance droplet concentrations? Journal of Geophysical Research 105 (D19), 24,351-24,361.

Gnauk, T., Brüggemann, E., Müller, K., Chemnitzer, R., Rüd, C., Galgon, D., Wiedensohler, A., Acker, K., Auel, R., Wieprecht, W., Möller, D., Jaeschke, W., Herrmann, H., 2005. Aerosol characterisation at the FEBUKO upwind station Goldlauter (I): particle mass, main ionic components, OC/EC, and mass closure. Atmospheric Environment (this issue).

Heinold, B., Tilgner, A., Jaeschke, W., Haunold, W., Knoth, O., Wolke, R., Herrmann, H., 2005. Meteorological characterisation of the FEBUKO hill cap cloud experiments, Part II: tracer experiments and flow characterisation with nested non-hydrostatic atmospheric models. Atmospheric Environment (this issue).

Herrmann, H., Ervens, B., Jacobi, H.-W., Wolke, R., Nowacki, P., Zellner, R., 2000. CAPRAM2.3: a chemical aqueous phase radical mechanism for tropospheric chemistry. Journal of Atmospheric Chemistry 36, 231-284.

Herrmann, H., Tilgner, A., Majdik, Z., Barzaghi, P., Gligorovski, S., Poulain, L., Monod, A., 2005. Towards a more detailed description of tropospheric aqueous phase organic chemistry: CAPRAM 3.0. Atmospheric Environment this issue.

Hinneburg, D., Knoth, O., 2005. Non-dissipative cloud transport in Eulerian grid models by adopting the volumeof-fluid method. Atmospheric Environment (this issue).

Knoth, O., 2005. A parcel model for the combined treatment of microphysical and multiphase chemistry processes. Atmospheric Environment (this issue).

Kreidenweis, S.M., Walcek, C.J., Feingold, G., Gong, W., Jacobson, M.Z., Kim, C., Liu, X., Penner, J.E., Nenes, A., Seinfeld, J.H., 2003. Mopdification of aerosol mass and size distribution due to aqueous phase $\mathrm{SO}_{2}$ oxidation in clouds: comparisons of several models. Journal of Geophysical Research 108 (D7), 4213.

Lehmann, K., Massling, A., Tilgner, A., Mertes, S., Galgon, D., Wiedensohler, A., 2005. Size-resolved soluble volume fractions of submicrometer particles in air masses of different character. Atmospheric Environment, this issue, doi:10.1016/j.atmosenv.2005.02.011.

Lelieveld, J., Crutzen, P.J., 1991. The role of clouds in tropospheric photochemistry. Journal of Atmospheric Chemistry 12, 229-267.

Leriche, M., Voisin, D., Chaumerliac, N., Monod, A., Aumont, B., 2000. A model for tropospheric multiphase chemistry: application to one cloudy event during the CIME experiment. Atmospheric Environment 34 (29/30), 5015-5036.

Leriche, M., Deguillaume, L., Chaumerliac, N., 2003. Modeling study of strong acids formation and partitioning in a polluted cloud during wintertime. Journal of Geophysical Research 108 (D14), 4433.

Mauersberger, G., 2005. ISSA (iterative screening and structure analysis) - a new reduction method and its application to the tropospheric cloud chemical mechanism RACM/ CAPRAM2.4. Atmospheric Environment (this issue). 
Mertes, S., Galgon, D., Schwirn, K., Nowak, A., Lehmann, K., Massling, A., Wiedensohler, A., Wieprecht, W., 2005a. Evolution of particle concentration and size distribution observed upwind, inside and downwind hill cap clouds at connected flow conditions during FEBUKO. Atmospheric Environment (this issue).

Mertes, S., Lehmann, K., Nowak, A., Massling, A., Wiedensohler, A., 2005b. Link between aerosol hygroscopic growth and droplet activation observed for hill cap clouds at connected flow conditions during FEBUKO. Atmospheric Environment (this issue).

Müller, K., Spindler, G., Maenhaut, W., Hitzenberger, R., Wieprecht, W., Baltensperger, U., ten Brink, H., 2004. INTERCOMP2000, a campaign to assess the comparability of methods in use in Europe for measuring aerosol composition. Atmospheric Environment 38, 6459-6466.

Müller, K., van Pinxteren, D., Plewka, A., Svrcina, B., Kramberger, H., Hofmann, D., Bächmann, K., Herrmann, H., 2005. Aerosol characterisation at the FEBUKO upwind station Goldlauter (II): detailed organic chemical characterisation. Atmospheric Environment (this issue).

Raes, F., Bates, T., McGovern, F., VanLiederke, M., 2000. The 2nd aerosol characterization experiment (ACE-2). General context and main results. Tellus B 52, 116-126.

Schwarzenböck, A., Heintzenberg, J., Mertes, S., 2000. Incorporation of aerosol particles between 25 and 850 nanometers into cloud elements: measurement with a new complementary sampling system. Atmospheric Research 54, 241-260.

Sehili, A.M., Wolke, R., Knoth, O., Simmel, M., Tilgner, A., Herrmann, H., 2005. Comparison of different model approaches for the simulation of multiphase processes. Atmospheric Environment (this issue).

Simmel, M., Wurzler, S., 2005. Condensation and nucleation in sectional cloud microphysical models based on the Linear Discrete Method. Atmospheric Research (submitted for publication).

Simmel, M., Diehl, C., Wurzler, S., 2005. Numerical simulation of the microphysics of an orographic cloud: comparison with measurements and sensitivity studies. Atmospheric Environment (this issue).

ten Brink, H., Maenhaut, W., Hitzenberger, R., Gnauk, T., Spindler, G., Even, A., Chi, X.G., Bauer, H., Puxbaum, H., Putaud, J.P., Tursic, J., Berner, A., 2004. INTER-
COMP2000: the comparability of methods in use in Europe for measuring the carbon content of aerosol. Atmospheric Environment 38, 6507-6519.

Tilgner, A., Heinold, B., Nowak, A., Herrmann, H., 2005a. Meteorological characterisation of the FEBUKO hill cap cloud experiments, Part I: synoptic characterisation of measurement periods. Atmospheric Environment (this issue).

Tilgner, A., Majdik, Z., Sehili, A.M., Simmel, M., Wolke, R., Herrmann, H., 2005b. SPACCIM: simulations of the multiphase chemistry occurring in the FEBUKO hill cap cloud experiments. Atmospheric Environment (this issue).

van Pinxteren, D., Plewka, A., Hofmann, D., Müller, K., Kramberger, H., Svrcina, B., et al., 2005. Schmücke hill cap cloud and valley stations aerosol chemical composition during FEBUKO (II): organic compounds. Atmospheric Environment (this issue).

Wieprecht, W., Acker, K., Mertes, S., Collett Jr., J.L., Jaeschke, W., Brüggemann, E., Möller, D., Herrmann, H., 2005. Cloud physics and cloud water sampler comparison during FEBUKO. Atmospheric Environment (this issue).

Wobrock, W., Schell, D., Maser, R., Jaeschke, W., Georgii, H.W., Wieprecht, W., Arends, B.G., Mols, J.J., Kos, G.P.A., Fuzzi, S., Facchini, M.C., Orsi, G., Berner, A., Solly, I., Kruisz, C., Svenningsson, B., Wiedensohler, A., Hansson, H.-C., Ogren, J.A., Noone, K.J., Hallberg, A., Pahl, S., Schneider, T., Winkler, P., Winiwarter, W., Colvile, R.N., Choularton, T.W., Flossmann, A.I., Borrmann, S., 1994. The Kleiner Feldberg Cloud Experiment 1990. An overview. Journal of Atmospheric Chemistry 19, 3-35.

Wobrock, W., Flossmann, A.I., Monier, M., Pichon, J.-M., Cortez, L., Fournol, J.-F., Schwarzenböck, A., Mertes, S., Heintzenberg, J., Laj, P., Orsi, G., Ricci, L., Fuzzi, S., ten Brink, H., Jongejan, P., Otjes, R., 2001. The cloud ice mountain experiment (CIME) 1998: experiment overview and modelling of the microphysical processes during the seeding by isentropic gas expansion. Atmospheric Research 58, 231-265.

Wolke, R., Sehili, A.M., Simmel, M., Knoth, O., Tilgner, A., Herrmann, H., 2005. SPACCIM: a parcel model with detailed microphysics and complex multiphase chemistry. Atmospheric Environment (this issue). 